\title{
AGROMETEOROLOGIA
}

\author{
Review Article
}

\section{THE IMPACT OF CLIMATIC VARIABILITY AND CLIMATE CHANGE ON ARABIC COFFEE CROP IN BRAZIL $\left({ }^{1}\right)$}

\author{
MARCELO BENTO PAES DE CAMARGO $\left({ }^{2}\right)$
}

\begin{abstract}
The climatic variability is the main factor responsible for the oscillations and frustrations of the coffee grain yield in Brazil. The relationships between the climatic parameters and the agricultural production are quite complex, because environmental factors affect the growth and the development of the plants under different forms during the growth stages of the coffee crop. Agrometeorological models related to the growth, development and productivity can supply information for the soil water monitoring and yield forecast, based on the water stress. A soil water balance during different growth stages of the coffee crop, can quantify the effect of the available soil water on the decrease of the final yield. Other climatic factors can reduce the productivity, such as adverse air temperatures happened during different growth stages. Solar radiation and relative humidity influence many physiological processes of the coffee tree but are not generally thought to play an important role as thermal and rainfall conditions in defining potential yield or ecological limitations for this crop. According to the last report of the Intergovernmental Panel on Climate Change (IPCC, 2007), the global temperature is supposed to increase $1.1^{\circ} \mathrm{C}$ to $6.4^{\circ} \mathrm{C}$ and the rainfall $15 \%$ in the tropical areas of Brazil. Some Global warming projections as presented by IPCC will cause a strong decrease in the coffee production in Brazil. According to the literature besides the reduction of suitable areas for coffee production, the crop will tend to move South and uphill regions. This review article analyze the effect that these possible scenarios would have in the agro-climatic coffee zoning in Brazil, and adaptive solutions, such as agronomic mitigations and development of cultivars adapted to high temperatures is considered.
\end{abstract}

Key words: Coffea arabica L., global warming, productivity, agronomic mitigations and adaptations, crop zoning.

(1) Receipted for publication in September 11, 2009 and accepted in December, 10, 2009.

$\left(^{2}\right)$ Centro de Ecofisiologia e Biofísica, Instituto Agronômico, Caixa Postal 28, 13012-970 Campinas (SP). Bolsista de Produtividade Científica do CNPq. 


\title{
RESUMO \\ IMPACTO DA VARIABILIDADE E DA MUDANÇA CLIMÁTICA NA PRODUÇÃO DE CAFÉ ARÁBICA NO BRASIL
}

\begin{abstract}
A variabilidade climática é o principal fator responsável pelas oscilações e frustrações da produção de café no Brasil. As relações entre os parâmetros climáticos e a produção agrícola são bastante complexas, pois fatores ambientais afetam o crescimento e o desenvolvimento das plantas sob diferentes formas durante as fases de crescimento da cultura do café. Modelos agrometeorológicos que relacionam o crescimento, desenvolvimento e a produtividade podem prover importantes informações para o monitoramento das condições hídricas da cultura e estimativa da produtividade com base no estresse hídrico. Resultados do balanço observados durante os diferentes estádios fenológicos quantificam o efeito da água disponível no solo sobre a produtividade da cultura. Outros fatores climáticos podem reduzir a produtividade, como temperaturas adversas ocorridas durante as diferentes fases críticas da cultura. Radiação solar e umidade relativa influenciam também os processos fisiológicos da planta, mas normalmente não penalizam a produtividade como as condições hídricas e térmicas. Segundo o último relatório do Painel de Intergovernamental de Mudanças Climáticas (IPCC), prevê-se que a temperatura global aumente de $1,1{ }^{\circ} \mathrm{C}$ a $6,4^{\circ} \mathrm{C}$ e a chuva em $15 \%$ nas áreas tropicais de Brasil. Alguns trabalhos inferem que estes cenários previstos pelo IPCC causarão forte redução na produção de café no Brasil, com tendência de se mover para regiões de altitude e Sul do Brasil. Este trabalho de revisão analisa o efeito que estes possíveis cenários teriam no zoneamento agroclimático do café arábica no Brasil; aborda também os métodos de adaptação e mitigação agronômicos como manejo e desenvolvimento de cultivares adaptadas a temperaturas elevadas
\end{abstract}

Palavras-chave: Coffea arabica L., aquecimento global, produtividade, mitigação e adaptação, zoneamento climático.

\section{INTRODUCTION}

The climatic variability is the main factor responsible for the oscillations and frustrations of the coffee grain yield in Brazil, especially in Minas Gerais, Espírito Santo, São Paulo, and Paraná States. The relationships between the climatic parameters and the agricultural production are quite complex, because environmental factors affect the growth and the development of the plants under different forms during the phenological phases of the coffee crop (CAMARGO and CAMARGO, 2001). Agro-meteorological models related to the growth, development and productivity can supply information for the soil water monitoring and yield forecast based on the air temperature and water stress derived by a water balance during different crop growth stages, quantifying the effect of the available soil water on the decrease of the final yield. The processes of photosynthesis become limited when water stress occurs, due to closing of the stoma and reduction in other physiological activities in the plant. Other climatic factors can reduce the productivity, such as adverse air temperatures happened during different growth stages.

Agro-meteorological studies were conducted aiming to develop agro-meteorological models (PICINI et al., 1999; SANTOS et al., 2006; CAMARGO et al., 2006; Camargo et al., 2007; Zacharias et al., 2008; Pezzopane et al., 2008; NunEs et al., 2008) that monitors and assess the quantitative influence of climatic variables, such as air temperature and soil water balance results on the coffee crop phenology and yield for different Brazilian regions. That kind of model could be an efficient tool to assess the environmental effects of new technologies, and future climate change scenarios.

On such background, this review article covers some aspects of the coffee crop responses under current climatic conditions and analysis of the impacts of climate variability and future climate scenarios issued from the Intergovernmental Panel on Climate Change (IPCC) would have in the agro-climatic zoning. Also, this review article analyzes the effect of adaptive solutions, such as agronomic mitigations and development of cultivars adapted to high temperatures.

\section{Climate and coffee production}

Among almost 100 species of the Coffea genus, Coffea arabica L. (arabica coffee) and e Coffea canephora Pierre ex Froehner (robusta coffee) economically dominate the world coffee trade, being responsible for about $99 \%$ of world bean production. Arabica coffee accounts for about $70 \%$ of coffee consumed, and robusta coffee for the rest (DAMATta and RAMALHO, 2006).

Arabica coffee is native to the tropical forests of Ethiopia, Kenya, and Sudan, at altitudes of 1500$2800 \mathrm{~m}$, between the latitudes of $4^{\circ} \mathrm{N}$ and $9{ }^{\circ} \mathrm{N}$. In this region, air temperature shows little seasonal 
fluctuation, with a mean annual air temperature between 18 and $22{ }^{\circ} \mathrm{C}$. Rainfall is well distributed, varying from 1600 to more than $2000 \mathrm{~mm}$, with a dry season lasting three to four months coinciding with the coolest period. In this environment, arabica coffee became established as an under-storey shrub (SYLVAIN, 1955). Arabica coffee is cultivated in more than $80 \%$ of the countries coffee grower, tends its largest diffusion in the American continent. In Asia, this species almost extinguished due, mainly, for the rust incidence (Hemileia sp.). Now Arabica coffee is in the high altitudes of India, where it is counted with resistant cultivars to the predominant races of this fungus, as well as in Philippines and in the Southeast region of Indonesia.

Arabica coffee vegetates and fructifies very well at tropical uplands, as in the Southeast area of Brazil. It is usually affected in their growth stages by the environmental conditions, especially by the photoperiodic variation and by the rainfall distribution and air temperature that interfere in the crop phenology, and consequently in the coffee bean productivity and quality.

According to CAMARGo (1985), for arabica coffee the optimums mean annual air temperature range from 18 to $23{ }^{\circ} \mathrm{C}$. Above $23^{\circ} \mathrm{C}$, fruit development and ripening are accelerated, often leading to loss of quality. Continuous exposure to daily temperatures as high as $30^{\circ} \mathrm{C}$ could result in not only depressed growth but also in abnormalities such as yellowing of leaves (DAMATTA and RAMALHO, 2006). A relatively high air temperature during blossoming, especially if associated with a prolonged dry season, may cause abortion of flowers. It should be noted, however, that selected cultivars under intensive management conditions have allowed arabica coffee plantations to be spread to marginal regions with mean annual air temperatures as high as $24-25^{\circ} \mathrm{C}$, with satisfactory yields, such as in the Northeast and North regions of Brazil (FAzUOLI et al., 2007a; BERGO et al., 2008). On the other hand, in regions with a mean annual air temperature below $18^{\circ} \mathrm{C}$, growth is largely depressed. Occurrence of frosts, even if sporadic, may strongly limit the economic success of the crop.

Robusta coffee is native to the lowland forests of the Congo River basin; with extend up to Lake Victoria in Uganda. This species developed as a midstorey tree in a dense, equatorial rainforest. In that region, the annual mean temperature range from 23 to $26{ }^{\circ} \mathrm{C}$, without large oscillations, with abundant rainfall superior to $2000 \mathrm{~mm}$ distributed over 9 to 10 month period. High temperatures can be harmful, especially if the air is dry (COSTE, 1992). Robusta is much less adaptable to lower temperatures than arabica. Both leaves and fruits do not withstand temperatures below $6^{\circ} \mathrm{C}$ or long periods at $15^{\circ} \mathrm{C}$. As altitude relates to temperature, robusta coffee can be growth between sea level and $800 \mathrm{~m}$, whereas arabica coffee grows better at higher altitudes and is often grown in hilly areas, as in Colombia and Central America. Robusta coffee grows better in areas with annual mean temperature among 22 to $26^{\circ} \mathrm{C}$, as in the Republic of Congo, Angola, Madagascar, Ivory Coast, Vietnam, Indonesia and Uganda. In Brazil the main areas that cultivate the robusta are the lowlands areas of the Espirito Santo (Southeast) and Rondonia (North) States.

\section{Global climate change and climatic variability}

The increase of greenhouse gas emissions (GHG) in the atmosphere is causing wide changes in atmospheric events, influencing climate change and variability with critical impacts on vegetations (MARENGO, 2007). According to the Fourth Assessment Report of the World Meteorological Organization (WMO) Intergovernmental Panel on Climate Change (IPCC, 2007), semi-arid and sub-humid regions of Asia, Africa and Latin America are likely to warm during this century and freshwater availability is projected do decrease. Agricultural productivity in tropical Asia is sensitive not only to temperature increases, but also to changes in the nature and characteristics of monsoon. In the semi-arid tropics of Africa, which area already having difficulty coping with environmental stress, climate change resulting in increased frequencies of drought poses the greatest risk to agriculture. In Latin America, the air temperature is supposed to increase $1.1^{\circ} \mathrm{C}$ to $6.4{ }^{\circ} \mathrm{C}$ and the rainfall $15 \%$ in the tropical areas of Brazil; and agriculture and water resources are most affected through the impact of extreme temperatures and changes in rainfall (SIVAKUMAR and STEFANSKI, 2008).

The report is obviously preoccupying, although the own reports contain a high uncertainty degree in the results of the long term forecast models. According to the IPCC (2007) macroclimatic characteristics are showing changes, particularly in the last decade. The parameters more representative of these variations are air temperature. Really in the last 10 years, the agriculture has been suffering with high air temperatures, especially during 2002 and 2007 years. Periods with accentuated water deficits have also been frequent in those years, what would confirm that the meteorological adversities are happening in an atypical way, reaching the Brazilian coffee crop. However, these agro-meteorological adversities have happened in cyclical form during the XX century. 
For instance, the 1960's decade was marked by severe droughts, especially during the years of 1961 and 1963, which affected drastically the coffee production for the years of 1962 and 1964 . Associated to these dry years, high air temperatures were observed, mainly during the months of August, September, and October, which were the highest of the XX century.

When we analyze the long term (119 years) meteorological data $(1890 / 2008)$ collection from the weather station of Campinas, Sao Paulo State, Brazil (Figures 1 and 2), we can observe that agrometeorological adversities (rainfall and mean air temperature) happened in a cyclical way, with typical periods from 15 to 20 years of variability, but these annual temperatures show an increase up to $2.0^{\circ} \mathrm{C}$ for annual mean, $1.3^{\circ} \mathrm{C}$ for the annual maximum, and $2.6{ }^{\circ} \mathrm{C}$ for the annual minimum (CAMARGO, 2008). For instance severe frosts, adversities that do not happen in the coffee crop of the Southeast region since 1994, are observed on average every 15-20 years (CAMARGO et al., 1993; Astolpho et al., 2004). Examples are the severe frosts of the years of 1892, 1902, 1918, 1942, 1953, 1975, 1981, and 1994 (CAMARGO et al., 2002).

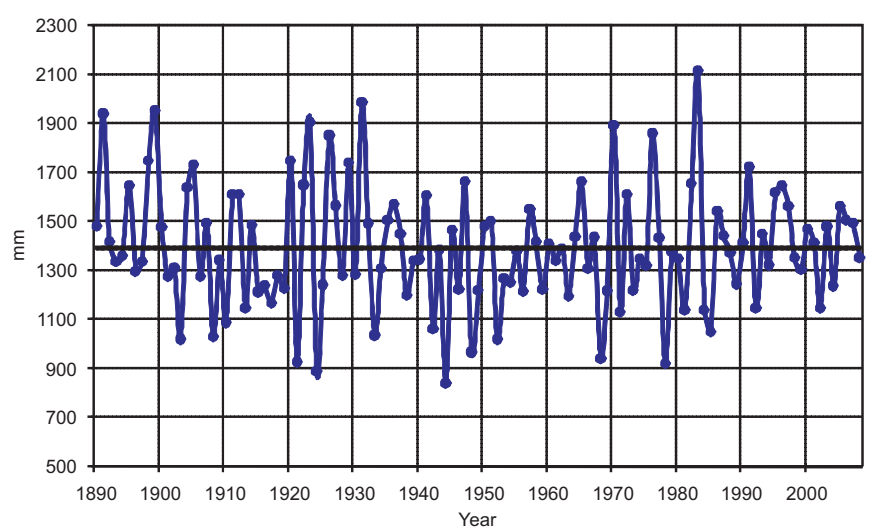

Figure 1. Yearly total precipitation for Campinas, São Paulo State, Brazil, from 1890 to 2008.

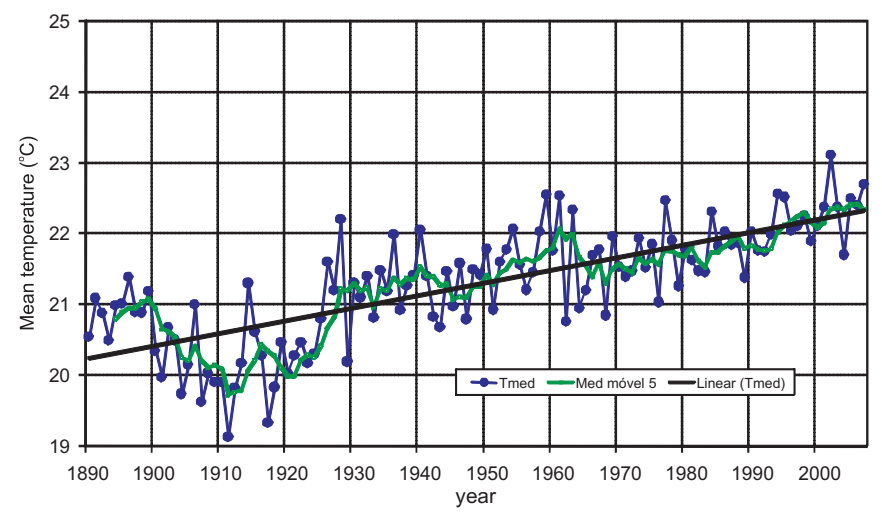

Figure 2. Annual mean air temperature for Campinas, Sâo Paulo State, Brazil, from 1890 to 2008.
According to the IPCC, the global warming scenario, the maximum air temperatures would be higher, but the minimum air temperatures would be lower and frosts would be also more frequent (ORLANDINI, 2008). Air temperature increases can lead to several consequences: faster physiologic plant growth, and therefore smaller final production; greater risk of pathogenic attacks and greater request for irrigation. Global Circulation Models (GCMs) can reproduce climate features on large scales, but their accuracy decreases when proceeding from continental to regional and local scales because of the lack of resolution (HALENKA, 2008). This is especially true for surface fields, such as precipitation, surface air temperature and their extremes, which are critically affected by topography and land use.

The scientific community responsible for the forecast of long period scenarios for next decades does not present consensus on the actual warming of the climate of the Earth. Among the reports of IPCC, spite all they contain warming scenarios, the fourth informed increases of 2 and $3{ }^{\circ} \mathrm{C}$, while the first report informed warming scenarios up to $10{ }^{\circ} \mathrm{C}$. Besides, a group of skeptical scientists (AвDUsAmatov, 2006; Molion, 2008) are defending inverse scenario up to the year of 2050, when the Earth would arrive to a great cooling, as it happened in the middle of 1700, when several European rivers got to freeze during the winter seasons. Forecast of distant scenarios, such as for 20, 50, 100 years, would be more inconsistent for the conclusion of how the scenarios of the climate will be for the agricultural activities.

\section{Possible consequences for the coffee crop}

High temperatures are known to disturb plant metabolism. Coffee cultivation in the open is the usual practice in Brazil, and this provokes leaf exposure to high irradiance and the absorption of much more energy than that usable by photosynthesis. Such conditions may cause an energy overcharge and to an overheating of leaves that, in extreme cases, can reach temperatures of $40{ }^{\circ} \mathrm{C}$ or even above, especially if stomata are closed, as occurs on sunny days in unshaded crops (MAESTRI et al., 2001).

A quality problem could arise, from the faster plant growth that will lead to lower coffee fruit quality. Besides, high maximum temperatures during summer months may cause an excessive fruit ripening, against fruit quality. Coffee trees are well resistant to high summer temperature and drought, but the increase of extreme conditions can be responsible of physiological stresses, such as the reduction of photosynthetic efficiency. Others critical phases are flowering and grain fill in relation with the anticipation of bud 
dormancy break. Moreover high temperature and dry conditions during the reproductive phase can be critical for the optimum coffee production and quality (CAmargo, 1985; Camargo and Camargo, 2001). The setting of adequate air temperature limits for coffee is decisive for the distribution and economic exploitation of the crop.

Taking into account the global warming phenomena as reported by the IPCC, in 2004, temperature may rise up to $5.8^{\circ} \mathrm{C}$ in the tropical area up the end of the XXI century. Some papers analyzed the vulnerability considering the actual genetic and physiological characteristics of the cultivated Brazilian cultivars of arabica coffee (Nobre et al., 2005; Zullo Junior et al., 2006; Damatta and Ramalho, 2006; Assad et al., 2007; Pinto et al., 2007) inferred that severe reductions of adequate areas for growing the crop are to be expected. The forecast of global warming has been causing great concern for scientists and producers linked to the Brazilian coffee crop. Some global warming reports get to infer scenarios that these reductions might reach values as high as $95 \%$ in the Brazilian states of Goias, Minas Gerais and Sao Paulo, and 75\% in Parana state (AssAD et al., 2004).

More recently taking into account the global warming by the IPCC (2007) other papers were published (PINTO et al., 2008a; b) concerning "Global Warming and the New Geography of the Agricultural Production in Brazil". The evaluation of the impacts of the climatic changes in the coffee crop was made using the climatic model PRECIS (Providing Regional Climates for Impact Studies) which is a computer program developed by the Hadley Center (England). The program based on annual mean air temperature and climatic risk zoning simulates the agricultural scenarios for the Brazilian coffee crop for the years of 2010, 2020, 2050 and 2070 in agreement with the forecasts of IPCC. The authors concluded that if no adaptation action be accomplished the warming up to $5.8^{\circ} \mathrm{C}$ foreseen for 2070 would cause many climatic changes and it would make unfeasible the coffee crop in the Southeast region of Brazil (Minas Gerais and Sao Paulo States). In 2070 the coffee crop will migrate for the South region (Parana, Santa Catarina and Rio Grande do Sul), where according to the authors frost risk will be much lower.

However, fundamental agroclimatic factors need to be considered such as different annual photoperiodic variation, rainfall distribution and especially the high frost risk occurrence in the Brazilian South region. The risk of occurrence of severe frosts increases exponentially starting from the north of the state of Paraná to the south end of the state of Rio Grande do Sul. These factors would make unfeasible the commercial cultivation of the arabic coffee.

Drought and high and low air temperatures are undoubtedly the major threats to agricultural crop production, and the possibility to develop projections of drought occurrence at the regional scale is a necessary step toward the definition of suitable adaptation strategies for the coffee sector. In deriving drought projections from regional climate scenarios, the capability of climate models to reproduce the key feature of the hydrological regime should be examined (CALANCA, 2008). In addition, from a risk analysis standpoint there is a pressing need to quantify uncertainties in the projections and provide probabilistic assessments of the impacts of climate change, including frost.

Climate change can have a wide range of effects on agricultural systems and we must adapt to these changes to ensure that agricultural production is not only maintained but is increased to support a growing world population (SмIтH et al., 2008). Local adaptation practices and those practices introduced by national development, research and extension organizations need to be collected from the respective organizations and evaluated at different levels. Different agronomic, water and policy management adaptation strategies needed to be considered.

\section{Agronomic technologies for mitigation and adaptation}

Climate change mitigation strategies which include interventions to reduce the sources or enhanced the sinks of greenhouse gases have a marked management component aiming at conservation of natural resources such as improved fertilizer use, use of water harvesting and conservation techniques. These strategies are equally consistent with the concept of sustainability. Adaptation strategies include initiatives and measures to reduce the vulnerability of agro-ecosystems to projected climate change, such as changing varieties, altering the timing or location cropping activities, improving the effectiveness of pest, disease and weed management practices, making better use of seasonal climate forecast etc. According to Sivakumar and STEFanski (2008) it is essential to develop and integrate Agriculture Mitigation and Adaptation Frameworks for Climate Change into sustainable development planning at the national and regional levels to cope with the projected impacts of climate change. 
Thus, comprehensive agro-meteorological adaptation policy guidelines, focusing on preparedness, mitigation and adaptation measures to support sustainable agricultural development, are needed to cope with the impacts of climate change/ variability (Мотна, 2008). Adaptation strategies may range from a change in crop cultivars to accommodate drought or shifts in temperature to extreme measures such as a total change in land use away from agriculture production (SMITH et al., 2008). Pertinent research from several sources is reviewed and examples are provided using IPCC climate change scenarios to demonstrate the effect that agronomical mitigations (production system and plant management) and agronomical adaptation (breeding programs) strategies may have on global warming in coffee crop areas of the world.

Under agronomical aspects some of the techniques that can be used to attenuate the impact of unfavorable air temperatures according to FAzUOLI et al. (2007a) are:

Shading management system (Arborization): Although native to shady environments, modern arabica coffee cultivars in Brazil grow well without shade and even may show higher productions than those of shaded trees, particularly in zones with adequate climate and soils (DAMATTA, 2004). The coffee cultivation was adapted and widespread for unshaded due to the highest latitudes $\left(19-24^{\circ} \mathrm{S}\right)$ and lower altitudes $(500-1300 \mathrm{~m})$ than the origin area. Great part of the arabica coffee cultivation in traditional countries like Colombia, Costa Rica, Guatemala, El Salvador and Mexico (PeEters et al., 2002) feels under arborization system where the coffee plants are close to the microclimate of their natural habitat. However, in Brazil there is an increasing trend in expanding coffee cultivation to marginal lands where water shortages and unfavorable temperatures may significantly constrain crop production. Coffee plantations have been also expanded towards warmer regions with prolonged droughts. In these harsh environments, the use of shading management is highly advisable in order to allow economic yields (DAMATTA and RENA, 2002) and make the environment more suitable for arabica coffee.

The effect of arborization in relation to the microclimate has been studied for many authors (BAGgio et al., 1997; Miguel et al., 1995; BeER et al., 1998; Peeters et al., 2002). These papers describe the arborization in a qualitative manner about the type of the tree utilized, crop density. However few papers are found in literature that characterize the microclimate quantitatively such as in a coffee and dwarf coconut or Prata Banana systems in Mococa,
Brazil (Pezzopane et al., 2003; 2007), in an arborizated systems in Colômbia (FARFAN-VALENCIA et al., 2003), in an agroflorestal system in Mexico (BARRADAs and FANJUL, 1986) and in an arborizated system with 'bracatinga' in Londrina, Paraná state, Brazil (CARAMORI et al., 1996). These works showed that the microclimate is strongly influenced by wind, soil type, water deficit vapor, temperature and solar radiation and those elements are dependent to the climate, the species utilized for arborization and the crop density.

There are several possible tree species for use as arborization, such as grevílea robusta, cedrinho, macadamia, rubber tree, banana prata, avocado, dwarfish coconut among others. The technique of the arborization allows thinner shading, with a density of around 60 to 70 shading tree plants per hectare.

The main effects of shading on the coffee crop provides associated with decreased of the air temperature fluctuations by as much as $2-3{ }^{\circ} \mathrm{C}$ and wind speeds, and increased air relative humidity (Pezzopane et al., 2008; Camargo et al., 2008). Shading has been adopted to avoid large reductions in night temperatures at high elevations, as in Kenya (CARR, 2001), or at high latitudes, as in Parana State (23-24 $\left.{ }^{\circ} \mathrm{S}\right)$, Southern Brazil (CARAMORI et al., 2003) in order to reduce frost damage.

Planting at high densities: this agronomic practice is the latest trend in Brazilian coffee growth. New coffee cultivars, such as IAC-Tupi 1669-33 and IAC-Obatã 1669-20 (FAzUOLI et al., 2007b) are of compact size and especially suitable for planting in smaller spacing among lines and among plants in the line (planting in row). Therefore, this practice presents smaller productions per plant, but increasing the production per area. Besides, stressing less the coffee plant, allows maintaining it more grown leaves, providing a suitable microclimate, with lower air temperatures inside the plant, in relation to the external environment (FAzUoli et al., 2007a).

Vegetated soil: according to THOMAZIELLO et al. (2000) the good agricultural practice recommends maintaining during the rainy season vegetated soil with weed in the middle between lines handled with agriculture implements. Besides the good soil conservation practice, the maintenance vegetated soil reduces the soil and air temperatures and allows a better plant root system distribution because the superficial roots are affected by the high air temperatures. This handling also increases the organic matter tenor and the soil water retention capacity making possible a more tolerant cultivation to the adverse climatic co-nditions. 
Irrigation: this practice has been the main factor to allow the establishment of the coffee plant in Brazilian marginal areas of low altitude in that the mean air temperatures are high for the usual cultivation of the arabica coffee.

Genetic Breeding: The genetic improvement of arabica and robusta plants in the "Centro de Café Alcides Carvalho" (IAC) has always emphasized the development of material with high yields, quality, strength, and longevity. The cultivars developed at the IAC include Bourbon, Icatu, Mundo Novo, Acaiá, Catuaí, Obatã IAC 1669-20, Tupi, and Ouro Verde, which represent more than $90 \%$ of the arabica coffee trees currently in production in Brazil. According to FAZUOLI et al. (2007b) the cultivar Obatã IAC 1669-20 is resistant to coffee leaf rust, compact size, suitable for planting in rows or at high densities, and especially good yield and quality.

BERGO et al. (2008) evaluated 40 cultivars of arabica and robusta coffee from 1994 to 2004 in Rio Branco region, state of Acre, Brazil, where the annual mean air temperature is close $25^{\circ} \mathrm{C}$. The study was carried out in the experimental field of Embrapa-Acre, and authors concluded that the best yield performance was the Obatã IAC 1669-20 cultivar with significant difference in relation to the other cultivars. The Obatã cultivar presented a mean yield of 49 sacks per hectare of clean coffee. This is an example of genetic improvement based on selective breeding of species arabica and robusta and of how improvement can contribute to the sustainability of coffee cultivation even under marginal lands with unfavorable air temperature.

\section{CONCLUSIONS}

1. Agronomic techniques can be used, alone or in a complementary way to mitigate extreme meteorological events and to face the challenge of climatic variability or global warming on coffee crop. Fundamental scientific research using different coffee crop management, genetic breeding and new molecular tools and focusing on this subject is high recommended, and the impact of the agronomic technologies on coffee copping systems particularly in marginal lands, is a challenge to be handled within the near future.

2. Under agronomical aspects some strategies may have on global warming in coffee crop that can attenuate the impact of unfavorable temperatures are agronomical mitigations such as shading management system (arborization), planting at high densities, vegetated soil, correct irrigation and agronomical adaptation with focus on breeding programs.
3. For the next decades the agriculture, especially the coffee crop will be more developed and protected with agronomic techniques of adaptation and mitigation that certainly will continue to be developed by the technical and scientific world coffee crop community.

\section{REFERENCES}

ABDUSAMATOV, $\mathrm{K}$. The price of sensations about the global warming and the global ice age. PRAVDA. Disponível em: http:/ / english.pravda.ru/science/earth/08-02-2006/75628climate-0. Acesso em 8/2/2006.

ASSAD, E,D,; PINTO, H.S.; ZULLO JR., J.; AVILA, A.M.H. Impacto das mudanças climáticas no zoneamento agroclimático do café no Brasil. Pesquisa Agropecuária Brasileira, v.39, p. 1057-1064, 2004.

ASSAD, E,D,; PINTO, H.S.; ZULLO JUNIOR, J.; MARIN, F.R. Mudanças climáticas e agricultura: Uma abordagem agroclimatológica. Ciência \& Ambiente, v.34, p.169-182, 2007.

ASTOLPHO, F.; CAMARGO, M.B.P.; BARDIN, L. Probabilidades mensais e anuais de ocorrência de temperaturas mínimas do ar adversas à agricultura na região de CampinasSP de 1891 a 2000. Bragantia, v.63, p. 141-147, 2004.

ASTOLPHO, F.; CAMARGO, M.B.P.; PEDRO JR., M.J.; PALLONE FILHO, W.J.; BARDIN, L. Regionalização de riscos de ocorrência de temperaturas mínimas absolutas anuais para o Estado de São Paulo com base em modelos probabilísticos e digitais de elevação. Bragantia, v.64, p. 139-148, 2005.

BAGGIO, A.J.; CARAMORI, P.H.; ANDROCIOLI, A.; MONTOYA, L. Productivity of southern Brazilian coffee plantations shaded by different stockings of Grevillea robusta. Agroforestry Systems, v. 37, p. 111-120, 1997.

BARRADAS, V.L.; FANJUL, L. Microclimatic characterization of shaded and open-grow coffee (Coffea arabica L.) plantations in Mexico. Agricultural and Forest Meteorology, v. 38, p. 101112, 1986.

BEER, J.; MUSCHLER, R.; KASS, D.; SOMARRIBA, E. Shade management in coffee and cacao plantations. Agroforestry Systems, v. 38, p. 139-164, 1998.

BERGO, C.L.; PEREIRA, R.C.A.; SALES, F. Avaliação de genótipos de cafeeiros arábica e robusta no estado do Acre. Ciência e Agrotecnologia, v.32, p. 11-16, 2008.

CAMARGO, A.P. Florescimento e frutificação de café arábica nas diferentes regiões cafeeiras do Brasil. Pesquisa Agropecuária Brasileira, v.20, p. 831-839, 1985.

CAMARGO, A.P.; CAMARGO, M.B.P. Definição e esquematização das fases fenológicas do cafeeiro arábica nas condições tropicais do Brasil. Bragantia, v.60, p. 65-68, 2001. 
CAMARGO, M.B.P., PEDRO JR, M.J.; ALFONSI, R.R.; ORTOLANI, A.A.; BRUNINI, O. Probabilidade de ocorrência de temperaturas mínimas absolutas mensais e anual no Estado de São Paulo. Bragantia, v.52, p.161-168, 1993.

CAMARGO, M.B.P.; ALFONSI, R.R.; CAMARGO, A.P.; MELLO, M.H.A.; ASTOLPHO, F. Geadas severas na região cafeeira de Campinas-SP de 1890-2001 e sua relação com o fenômeno El Niño Oscilação Sul. Revista Brasileira de Agrometeorologia, v.10, p.123-127, 2002.

CAMARGO, M.B.P.; SANTOS, M.A.; PEDRO JR., M.J.; FAHL. Agrometeorological model for monitoring and predicting coffee (Coffea arabica L.) productivity in Sao Paulo State, Brazil. In: INTERNATIONAL CONFERENCE ON COFFEE SCIENCE, $21^{\text {st }}$, September 2006. Montpellier, France. Proceedings... ASIC: Montpellier: 2006. p.1125-1131.

CAMARGO, M.B.P., ROLIM, G.S., SANTOS, M.A. Modelagem agroclimatológica do café: estimativa e mapeamento das produtividades. Informe Agropecuário, v.28, p.58 - 65, 2007.

CAMARGO, M.B.P.; ROLIM, G.S.; SOUZA, P.S.; GALLO, P.B. Air temperature in different Coffea arabica microclimates arborized with dwarf coconut palm and rubber tree in Mococa, SP, Brazil. In: INTERNATIONAL CONFERENCE ON COFFEE SCIENCE, 22 ${ }^{\text {nd }}, 2008$, Campinas, Brazil. Proceedings... Campinas: ASIC, 2008. p.1247-1250

CAMARGO, M.B.P. The impact of climatic variability on the coffee crop. In: INTERNATIONAL CONFERENCE ON COFFEE SCIENCE, 22 ${ }^{\text {nd }}, 2008$, Campinas, Brazil. Proceedings..., Campinas: ASIC, 2008. p.1058-1065.

CARAMORI, P.H.; ANDROCIOLI FILHO, A.; LEAL, A.C. Coffee shade with Mimosa scabrella Benth for frost protection in southern Brazil. Agroforestry Systems, v.33, p.205-214, 1996.

CARAMORI, P.H.; GRODZKI, L.; MORAIS, H.; JULIATO, H. Efeito da geada em mudas de café sob diferentes métodos de proteção. In: SIMPÓSIO DE PESQUISA DOS CAFÉSDO BRASIL, 3., 2003. Porto Seguro. Anais... Porto Seguro: Consórcio Brasileiro de Pesquisa e Desenvolvimento do Café, 2003. p.1-6.

CARR, M.K.V.; The water relations and irrigation requirements of coffee. Experimental Agriculture, v.37, p.1$36,2001$.

COSTE, R. Coffee: The plant and the product. 1.ed. London: MacMillan Press, 1992. 328p.

DAMATTA, F.M.; RENA, A.B. Ecofisiologia de cafezais sombreados e a pleno sol. In: ZAMBOLIM, L. (Ed.). O estado da arte de tecnologias na produção de café. 1.ed. Viçosa: Universidade Federal de Viçosa, 2002. p.93-135.

DAMATTA, F.M. Ecophysiological constraints on the production of shaded and unshaded coffee: a review. Fields Crops Research, v.86, p. 99-114, 2004.

DAMATTA, F.M.; RAMALHO, J.D.C. Impacts of drought and temperature stress on cofeee physiology and production: a review. Brazilian Journal of Plant Physiology, v.18, p. 55-81, 2006.
FARFAN-VALENCIA, F.; ARIAS-HERNANDEZ, J.J.; RIANOHERRERA, N.M. Deasarrollo de una metodologia para medir sombrio en sistemas agroflorestales com café. Cenicafé, v. 54, p. 24-34, 2003.

FAZUOLI, L.C.; THOMAZIELLO, R.A.; CAMARGO, M.B.P. Aquecimento global, mudanças climáticas e a cafeicultura paulista. O Agronômico, v.59, p.19-20, 2007a.

FAZUOLI, L.C.; SILVAROLA, M.B.; SALVA, T.J.G. et al. Cultivares de café arábica do IAC. O Agronômico, v.59, p.12$17,2007 \mathrm{~b}$.

HALENKA, T. New sources of high resolution climate change scenarios for impact studies in agriculture. In: SYMPOSIUM ON CLIMATE CHANGE AND VARIABILITY: Agrometeorological monitoring and coping strategies for agriculture. Oscarsborg, Norway, Abstracts. WMO, p.49, 2008.

IPCC. Intergovernmental Panel on Climate Change. Climate Change, 2007: The physical science basis. Working Group I Report. Disponível em: http:/ / www.ipcc.ch/ipccreports/ar4wg1.htm. Acesso em 2007.

MAESTRI, M.; BARROS, R.S.; RENA, A.B. Coffee. In: LAST, F.T. (Ed.). Tree crop ecosystems. 1.ed. Amsterdam: Elsevier Publishers, 2001. p.339-360.

MARENGO, J.A. Cenários de mudanças climáticas para o Brasil em 2100. Ciência \& Ambiente, v.34, p.100-125, 2007.

MIGUEL, A.E.; MATIELLO, J.B.; CAMARGO, A.P.; ALMEIDA, S.R.; GUIMARÃES, S.R. Efeitos da arborização do cafezal com Grevillea robusta nas temperaturas do ar e umidade do solo, Parte II. In: CONGRESSO BRASILEIRO DE PESQUISAS CAFEEIRAS, 21., 1995, Rio de Janeiro. Trabalhos apresentados... Rio de Janeiro: PROCAFE, 1995. p.55-60.

MOLION, L.C.B. Aquecimento global, El Niño, manchas solares, vulcões, e oscilação decadal do Pacífico. Disponível em: http:/ / www.cptec.inpe.br. Acesso em 2008.

MOTHA, R.P. Developing an adaptation strategy for sustainable agriculture. In: SYMPOSIUM ON CLIMATE CHANGE AND VARIABILITY: Agro-meteorological monitoring and coping strategies for agriculture. 2008, Oscarsborg, Norway, Abstracts... Oscarsborg: WMO, 2008. p.49.

NOBRE, C.A.; ASSAD, E.D.; OYAMA, M.D. O impacto do aquecimento global nos ecossistemas brasileiros e na agricultura. Scientific American Brasil, v.12, p.70-75, 2005.

NUNES, F.L.; CAMARGO, M.B.P.; FAZUOLI, L.C.; PEZZOPANE, J.R.M. Estimation of the duration of the flowering-maturation stage for different arabic coffee cultivars. In: INTERNATIONAL CONFERENCE ON COFFEE SCIENCE, $22^{\text {nd }}, 2008$, Campinas, Brazil. Proceedings... Campinas: ASIC, 2008. p.1267-1270.

PEETERS, L.Y.K.; SOTO-PINTO, L.; PERALES, H.; MONTOYA, G.; ISHIKI, M. Coffee production, timber, and firewood in traditional and Inga-shaded plantations in Southern Mexico. Agriculture, Ecossystems and Environment, v.82, p.1-13, 2002. 
PEZZOPANE, J.R.M.; GALLO, P.B.; PEDRO JÚNIOR, M.J.; ORTOLANI, A.A. Caracterização microclimática em cultivo consorciado café/coqueiro-anão verde. Revista Brasileira de Agrometeorologia, v.11, p.293-302, 2003.

PEZZOPANE, J.R.M.; PEDRO JÚNIOR, M.J.; GALLO, P.B. Caracterização microclimática em cultivo consorciado café/ banana. Revista Brasileira de Engenharia Agrícola e Ambiental, v.11, p.256-264, 2007. (on-line)

PEZZOPANE, J.R.M.; PEDRO JR, M.J.; CAMARGO, M.B.P.; FAZUOLI, L.C. Exigência Térmica do Café Arábica CV. Mundo Novo no Subperíodo florescimento-colheita. Ciência e Agrotecnologia, v.32, p.1781-1786, 2008.

PICINI, A.G.; CAMARGO, M.B.P.,ORTOLANI, A.A.; FAZUOLI, L.C.; GALLO, P.B. Desenvolvimento e teste de modelos agrometeorológicos para estimativa de produtividade do cafeeiro. Bragantia, v.58, p.157-170, 1999.

PINTO, H.S.; ZULLO JR., J.; ASSAD, E.D.; EVANGELISTA, B.A. O aquecimento global e a cafeicultura brasileira. Boletim da Sociedade Brasileira de Meteorologia, v.31, p.65-72, 2007.

PINTO, H.S.; ASSAD, E.D.; ZULLO JR., J. et al. Aquecimento global e a nova geografia da produção agrícola no Brasil. Campinas: Embrapa/Unicamp, 2008a. 81p.

PINTO, H.S.; ZULLO JR.,J.; ASSAD, E.D. Calientamento global y La agricultura Brasileña. In: DIRVEN, M., RODRIGUEZ, A. (Ed.). La agricultura outra victima del cambio climatico. Santiago: Le Monde Diplomatic, Cepal, 2008b. p. 63-74.

SANTOS, M.A., CAMARGO, M. B. P. Parametrização de modelo agrometeorológico de estimativa de produtividade do cafeeiro (Coffea arabica L.) nas condições do Estado de São Paulo. Bragantia, v.65, p.173-183, 2006.

SIVAKUMAR, M.V.K.; STEFANSKI, R. Climate change mitigation, adaptation and sustainability in agriculture. In: SYMPOSIUM ON CLIMATE CHANGE AND VARIABILITY: Agro-meteorological monitoring and coping strategies for agriculture. 2008, Oscarsborg, Norway. Abstracts... Oscarsborg: WMO, 2008. p.44.

SMITH, W.; DESJARDINS, R.; GRANT, B. Some perspectives on agricultural GHG mitigation and adaptation strategies with respect to the impact of climate change-variability in vulnerable areas. In: SYMPOSIUM ON CLIMATE CHANGE AND VARIABILITY: Agro-meteorological monitoring and coping strategies for agriculture. 2008, Oscarsborg, Norway. Abstracts... Oscarsborg: WMO, 2008. p.44.

THOMAZIELLO, R.A.; FAZUOLI, L.C.; PEZZOPANE, J.R.M.; FAHL, J.I.; CARELLI, M.L.C. Café arábica: cultura e técnicas de produção. 1.ed. Campinas: Instituto Agronômico, 2000. 82p. Boletim Técnico n.187)

ZACHARIAS, A.O.; CAMARGO, M.B.P.; FAZUOLI, L.C. Modelo agrometeorológico de estimativa do início da florada plena do cafeeiro. Bragantia, v.67, p.249-256, 2008.
ZULLO JR., J.; PINTO, H.S.; ASSAD, E.D. Impact assessment study of climate change according IPCC prognostics on Brazilian agricultural zoning. Meteorological Applications, Royal Meteorological Society, v.1, p.69-80, 2006. 